\title{
Cell surface sphingomyelin: key role in cancer initiation, progression, and immune evasion
}

\author{
Hatem Tallima ${ }^{1,2^{*}}$ (D) Hassan M. E. Azzazy ${ }^{1}$ (D) and Rashika El Ridi²
}

\begin{abstract}
Cell surface biochemical changes, notably excessive increase in outer leaflet sphingomyelin (SM) content, are important in cancer initiation, growth, and immune evasion. Innumerable reports describe methods to initiate, promote, or enhance immunotherapy of clinically detected cancer, notwithstanding the challenges, if not impossibility, of identification of tumor-specific, or associated antigens, the lack of tumor cell surface membrane expression of major histocompatibility complex (MHC) class I alpha and $\beta 2$ microglobulin chains, and lack of expression or accessibility of Fas and other natural killer cell immune checkpoint molecules. Conversely, SM synthesis and hydrolysis are increasingly implicated in initiation of carcinogenesis and promotion of metastasis. Surface membrane SM readily forms inter- and intra- molecular hydrogen bond network, which excessive tightness would impair cell-cell contact inhibition, inter- and intra-cellular signals, metabolic pathways, and susceptibility to host immune cells and mediators. The present review aims at clarifying the tumor immune escape mechanisms, which face common immunotherapeutic approaches, and attracting attention to an entirely different, neglected, key aspect of tumorigenesis associated with biochemical changes in the cell surface that lead to failure of contact inhibition, an instrumental tumorigenesis mechanism. Additionally, the review aims to provide evidence for surface membrane SM levels and roles in cells resistance to death, failure to respond to growth suppressor signals, and immune escape, and to suggest possible novel approaches to cancer control and cure.
\end{abstract}

Keywords: Tumor, TAA, TSA, MHC class I, Natural killer cells, Sphingomyelin, Ceramide

\section{Introduction}

After decades of scientific investigations and billions of dollars, the option to the cancer drama remains surgery, provided the tumor is operable. The second option is radiation and chemotherapy, which potentially undermine the host immune responses. The third option is some attempts at personalized immunotherapy available uniquely at the most advanced centers in the developed countries and for the richest; however, with limited success rates [1]. Immunotherapy of cancer is

\footnotetext{
* Correspondence: htallima@aucegypt.edu

'Department of Chemistry, School of Science and Engineering, The American University in Cairo, New Cairo, Cairo 11835, Egypt

${ }^{2}$ Zoology Department, Faculty of Science, Cairo University, Giza 12613, Egypt
}

predominantly a change of focus from direct targeting of cancer cells to generating tumor-reactive immune cells. Immune-therapy involves generation or activation of host immune effectors directed to tumor-specific (TSA) or associated (TAA) antigens, which are presented on the cell surface. Immunological approaches in cancer management that neglect lack of tumor cells surface membrane expression of TSA or TAA, MHC class I molecules, and natural killer (NK) cells activating checkpoints may not be effective [2].

Antigen presentation by tumor cells involves generation, proteasome proteolysis, entry into the endoplasmic reticulum for possible binding to HLA class I molecules, followed by transfer to the cell surface of a

C C The Author(s). 2021 Open Access This article is licensed under a Creative Commons Attribution 4.0 International License, which permits use, sharing, adaptation, distribution and reproduction in any medium or format, as long as you give appropriate credit to the original author(s) and the source, provide a link to the Creative Commons licence, and indicate if changes were made. The images or other third party material in this article are included in the article's Creative Commons licence, unless indicated otherwise in a credit line to the material. If material is not included in the article's Creative Commons licence and your intended use is not permitted by statutory regulation or exceeds the permitted use, you will need to obtain permission directly from the copyright holder. To view a copy of this licence, visit http://creativecommons.org/licenses/by/4.0/ The Creative Commons Public Domain Dedication waiver (http://creativecommons.org/publicdomain/zero/1.0/) applies to the data made available in this article, unless otherwise stated in a credit line to the data. 
complex comprising a "putative" TAA or TSA [2]. The review challenges the existence of such antigens and accessibility of tumor cells surface MHC class I and NK cell activating molecules, thus precluding antigen presentation and preventing any immune attack mode on the cancer cells. Conversely, the review highlights the most fundamental concept of "contact inhibition", now largely ignored, and which refers to contact-mediated inhibition of locomotion, migration, and proliferation when normal cells come in contact with one another [3]. Failure of contact inhibition is one of the major mechanisms underlying the initiation of tumorigenesis and is certainly the responsibility of the cell surface phospholipids, cholesterol, and sphingomyelin (SM). Therefore, attention is herein directed to the cell surface biochemical and biophysical changes in SM levels and instrumental roles in cancer initiation, growth, and metastasis (Fig. 1). The release of diacyl glycerol upon SM synthesis is clarified in Fig. 1. This molecule is central to a too large plethora of metabolic and signaling pathways, and its role in tumorigenesis encompasses several axes, and is not restricted to the content of plasma membrane SM.

\section{Tumor immune evasion}

Tumor-associated and tumor-specific antigens

Many tumor-associated (TAA) and tumor-specific (TSA) antigens are proteins expressed in fetal and normal adult tissues and stressed cells, found to be upregulated in cancer cells and serum of cancer patients (Table 1). All these molecules are actually self-antigens which may not induce immune responses specific to the tumor cells, even if they are displayed on the apical surface. They have diagnostic and prognostic value, but may not be instrumental in induction of immune effectors against cancer cells [4-12]. The extreme difficulty and challenges in identifying genuine TAA or TSA, which possess the needed specificity and immunogenicity, were recently emphasized [13-16].

Immunogenicity of the elusive tumor-associated antigens A putative TAA released by proliferating or dying tumor cells would be presented by macrophages or dendritic cells to stimulate CD4+ and then CD8+ T lymphocytes and B cells, provided proper co-stimulatory signals are available. That is not the case in numerous situations, as protein antigens fail to stimulate innate immunity receptors with consequent inflammation and pain, which are often not perceived during tumor initiation and growth [2]. The importance of these signals is shown by the phenomenon termed abscopal effect, whereby some immunogenic tumors regress following distant thermal or irradiation intervention, which results in release of endogenous damage-associated molecular patterns [1719]. The abscopal effect would certainly be effective

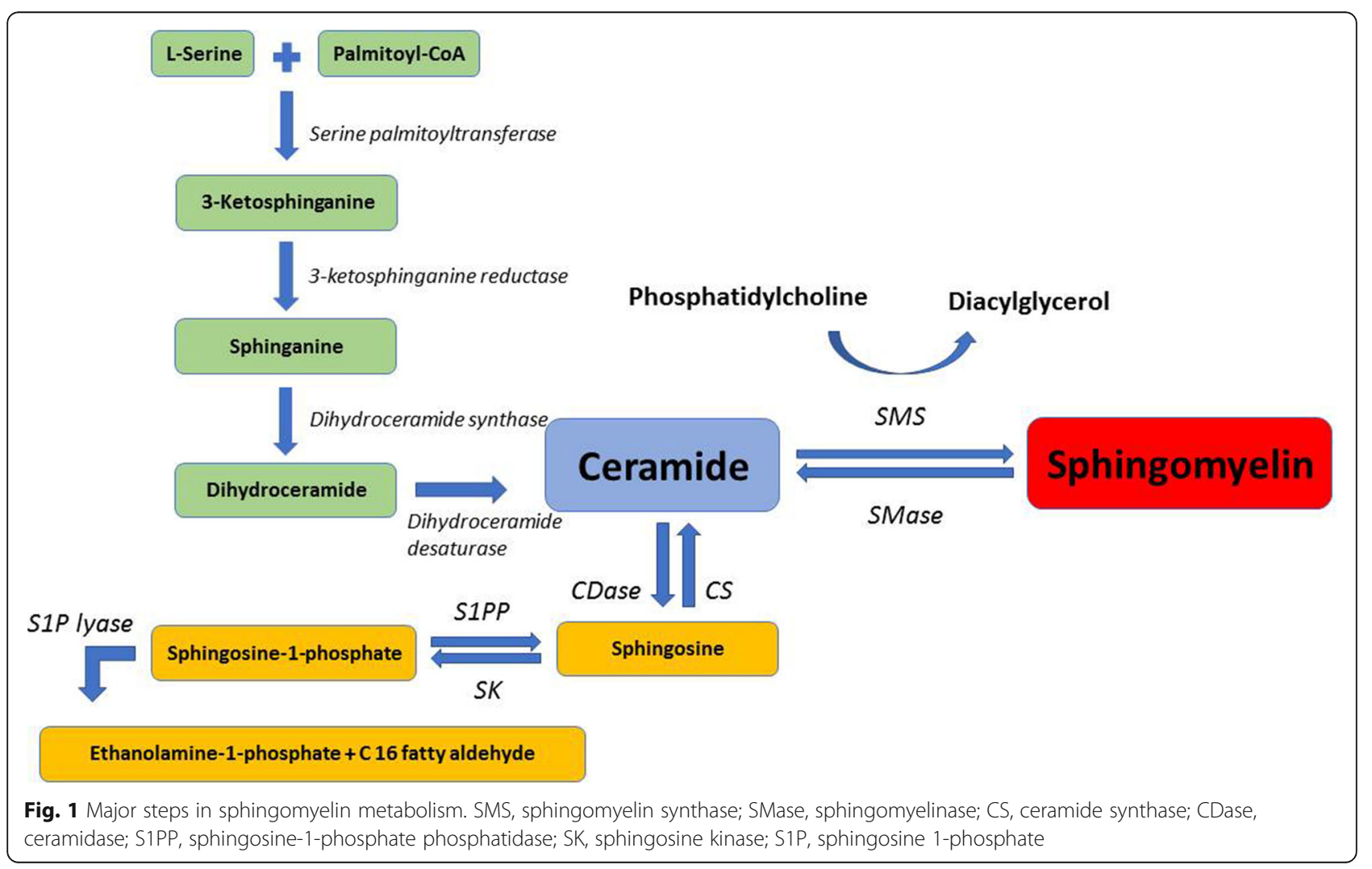


Table 1 Tumor-associated and tumor-specific antigens

\begin{tabular}{|c|c|c|c|c|}
\hline Marker & Full name & Tissue & Malignancy & Ref \\
\hline$\overline{\mathrm{AFP}}$ & Alfa fetoprotein & Fetal liver & Liver, gut, ovaries & [4] \\
\hline CEA & Carcinoembryonic antigen & Blood & Gastric, lung & {$[4]$} \\
\hline HSP & Heat shock proteins & Stressed cells & lung, gut, prostate & [4] \\
\hline$C A$ & Carbohydrate antigens & All cells & Gastric, lung, pancreas & [4] \\
\hline MUC1 & Mucin 1 & Epithelial cells & Lung, breast, pancreas & {$[4]$} \\
\hline PSA & Prostate-specific antigen & Prostate & Prostate & [4] \\
\hline MAGE & Melanoma-associated antigen & Testis & Lung & {$[4,5]$} \\
\hline NY-ESO-1 & Cancer/testis antigen & Testis & Esophagus & {$[6-8]$} \\
\hline SSX-2 & Cancer/testis antigen & Testis & Various cancer & {$[7,9,10]$} \\
\hline GPC3 & Glypican-3 & Fetal and adult & Liver, lung, melanoma & [4] \\
\hline Midkine & Growth-promoting factor 2 & All cells & Nervous system & {$[7,11]$} \\
\hline EpCAM & Cell adhesion molecule & Epithelial cells & Epithelial carcinomas & [7] \\
\hline PRAME & Preferentially in melanoma & Testis & Lung & {$[5,7,8]$} \\
\hline WT1 & Wilm's tumor protein 1 & Urinogenital & Kidney & {$[7,8]$} \\
\hline Survivin & Inhibitor of apoptosis & All cells & Bladder & {$[7,8,12]$} \\
\hline
\end{tabular}

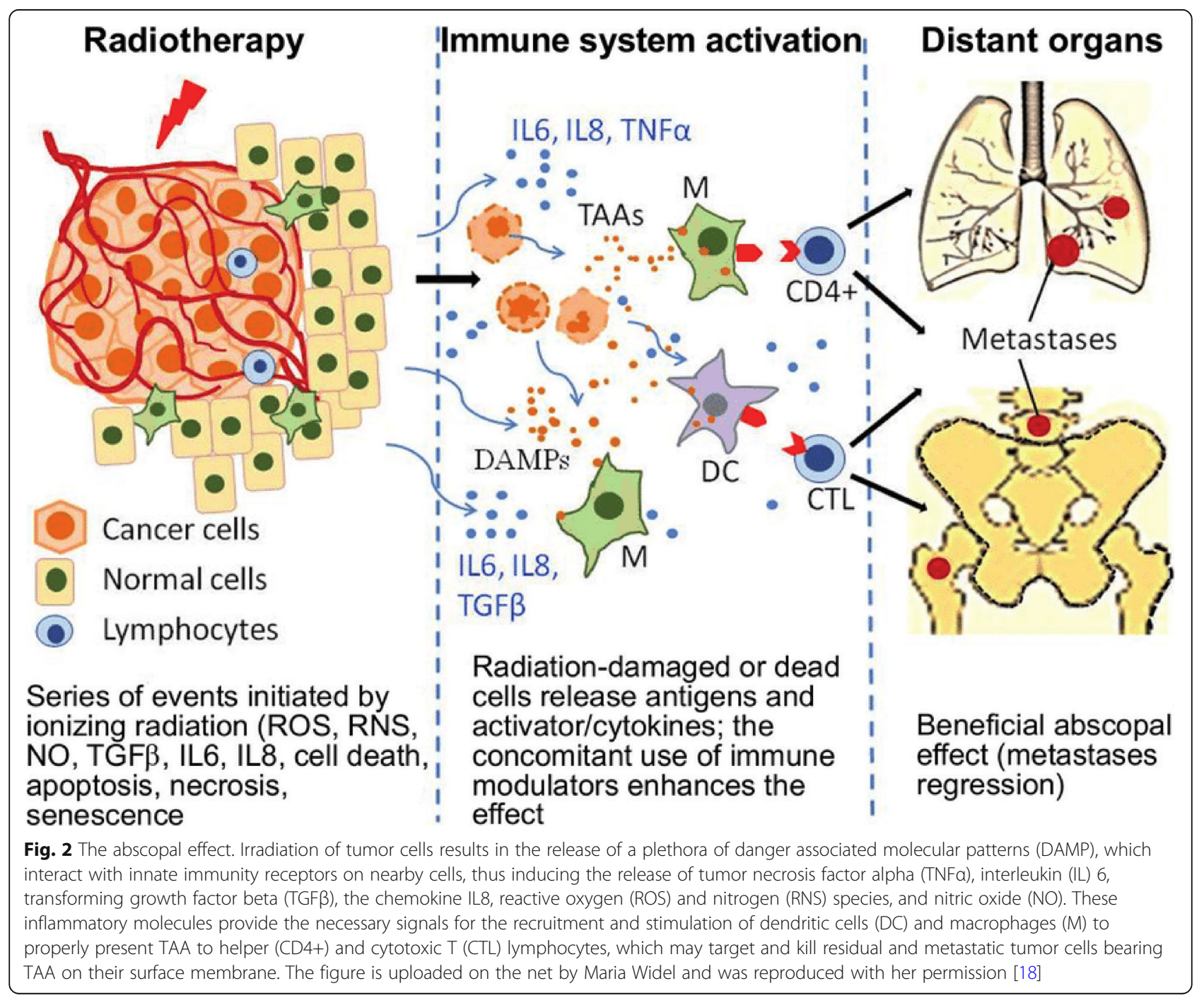


provided tumors are able to display surface membranelocated TSA or TAA (Fig. 2).

\section{Humoral antibody targeting of putative TAA-bearing tumor cells}

A TAA would then be the target of specific antibodies. If IgM or IgG1 specific antibodies are generated and access that tumor specific surface antigen, the complement system could be activated with limited effect on the tumor cell per se, but with considerable impact on the tumor microenvironment and on the host, if such antigen is shared with normal cells, especially in the lung and kidney. Antibodies that mediate natural killer (NK) cells and macrophage killing are more effective in tumor eradication, provided that antigen is expressed on the cell surface membrane (Fig. 3), and is specific to the tumor cells, not present as well on the surface of healthy epithelial, nervous system, and urogenital cells [4-12]. In fact, immunotherapy-generated antibodies will intensely engage with live or dying tumor cells-excreted and secreted products leading to their opsonization, while sparing the tumor cells.

Cytotoxic CD8+ cells targeting of tumor cells and the lack of surface membrane MHC class I molecule expression Specific CD8+ cytotoxic lymphocytes would be lifesaving if such putative TAA-derived peptides are presented on the surface of the tumor cells in association with MHC class I molecules (Fig. 4). Loss of surface membrane MHC class I molecule expression on cell surface membrane has, however, been documented for almost all tumors, and was found to be associated with a more malignant phenotype [for review [20-23]].

\section{Interaction of natural killer cells with tumor cells}

Despite such bleak scenario, it is fortunate that tumor cells displaying decrease or absence of surface membrane MHC class I molecules, invite NK cells into action, provided tumor necrosis factor (TNF) apoptosisinducing receptor, Fas (also termed CD95 or Apo-1 or TNFRSF6) [24] and death-inducing receptors, TRAIL (TNF-related apoptosis-inducing ligand)- R1 (death receptor (DR) 4 and TRAIL-R2 (DR5) [25, 26], and NK cell-activating molecules $[27,28]$ are displayed on the surface of the cancer cell (Fig. 5). It is likely NK cellmediated killing mechanisms are instrumental in immune surveillance responsible for elimination of tumors during human life span [27-29]. If age, hormonal, neural, biochemical and immune factors lead to NK cell activity impairment, cancer cells would overgrow, and gradually show loss of accessibility of Fas and NK cell activating molecules. Several cancer cell lines showed little surface membrane Fas expression even after treatment with interferon-gamma (IFN- $\gamma$ ) [30]. Additionally, several reports have documented cancer cell surface membrane aberrant expression of ligands to NK cell activating and inhibitory receptors [31-33].

\section{The cell surface changes as initiators of carcinogenesis} In case of tumor cell surface membrane aberrant expression of TSA or TAA, MHC class I, and NK cells activating molecules, immunotherapeutic approaches that

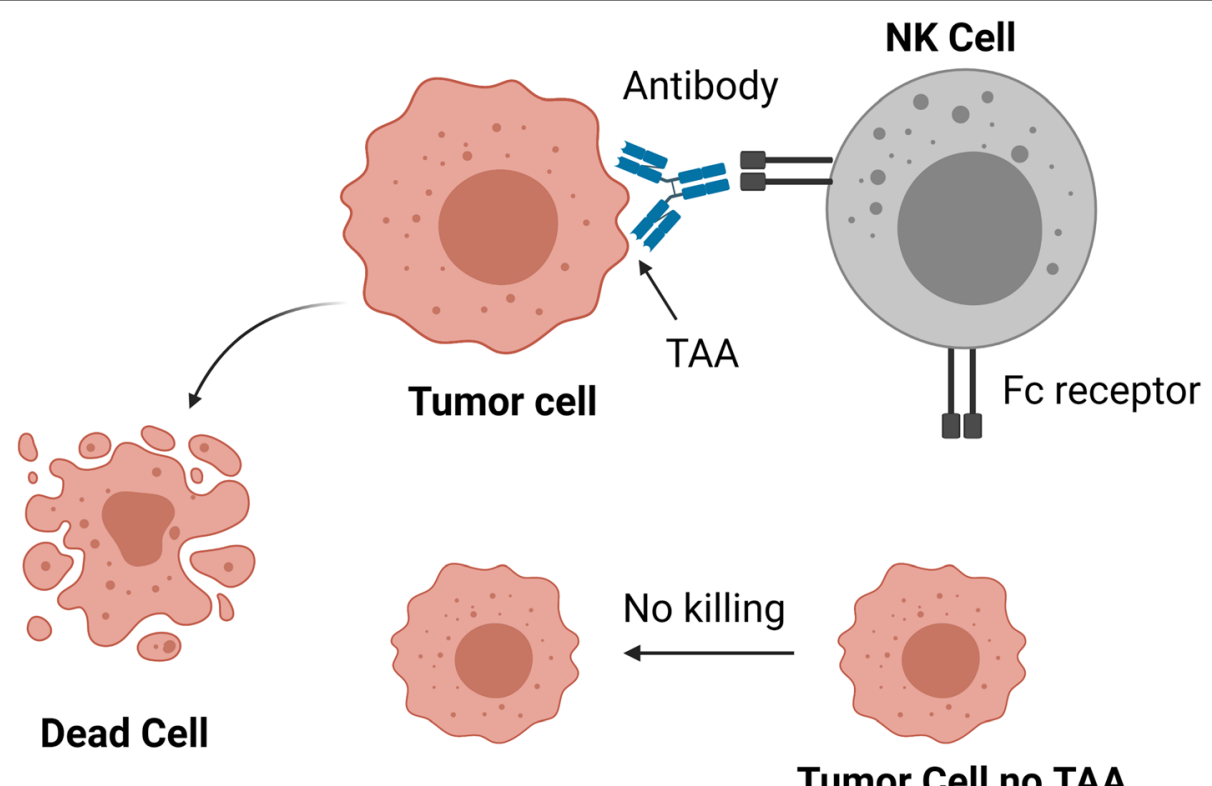

Tumor Cell no TAA

Fig. 3 Antibody-dependent cell-mediated cytotoxicity (ADCC). Natural killer cells (NK) killing of tumor cells relies on their expression of surface membrane tumor-associated antigen (TAA). Drawn using BioRender 


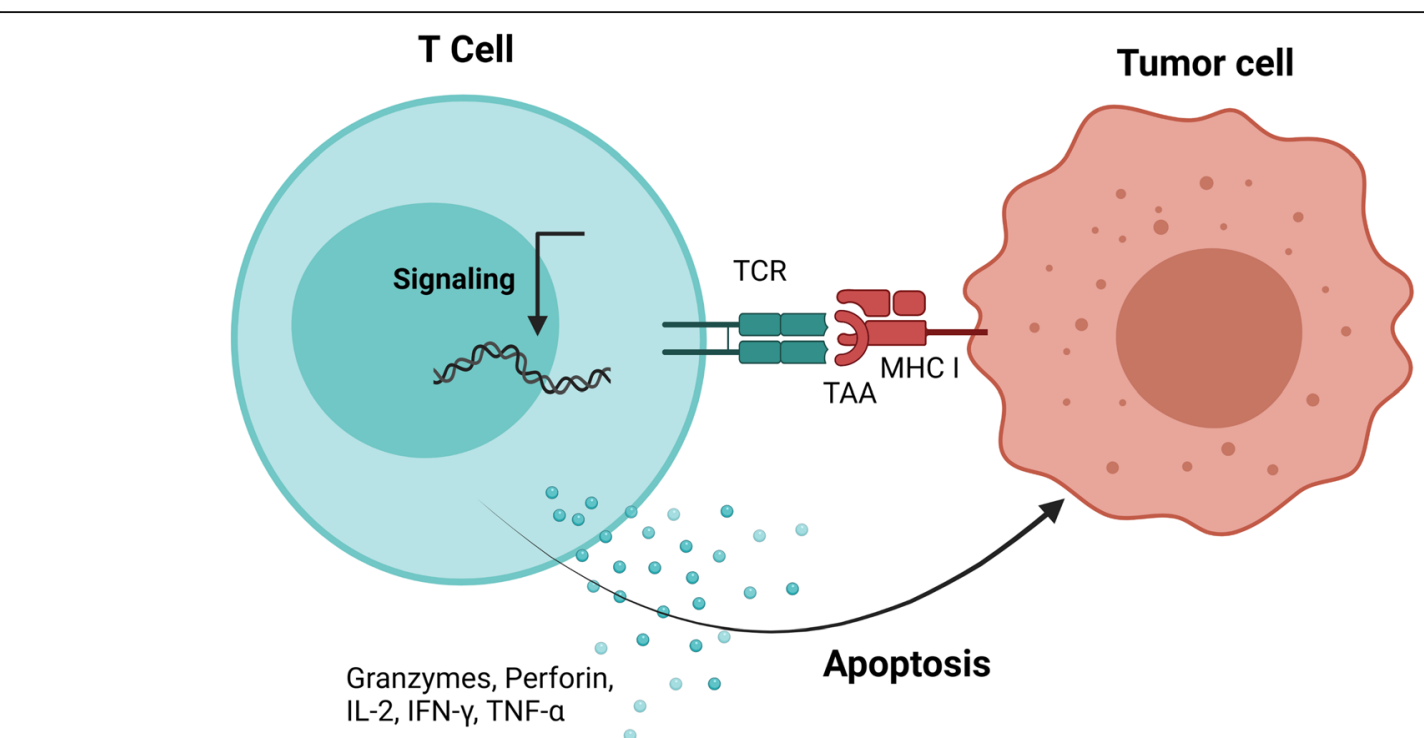

Fig. 4 Cytotoxic T lymphocyte killing of tumor cells. Presentation of peptide TAA-derived peptides by surface membrane MHC class I molecule is mandatory for mediating killing by cytotoxic T cells. TCR, T cell receptor, IFN- $\gamma$, interferon gamma. Drawn using BioRender

manipulate number and activity of antibody, CD4+, CD8+, NK cells and macrophages are of limited effect. The target of intervention should be the reason(s) behind decrease or lack of antigen expression, and most importantly, accessibility on the surface of cancer cells. Altered expression of surface membrane molecules has been ascribed to loss or reduction of gene expression, post translational modifications that prevented anchoring in surface membranes, hiding due to changes in the biochemical composition of cancer cells, or defects in the plasma membranes of cells that likely lead to loss or decrease of antigen exposure [20-23]. It is the biophysics and biochemistry of the cell surface that must be thoroughly examined in view of finding reliable solutions [34-39]. Changes in cell surface composition, electrical charge, and activity may be the reason for the loss of contact inhibition, which is directly related to the uncontrolled tumor cell proliferation [34-39]. The high net negative charge on the surface of tumor cells was ascribed to increase in phospholipids and was found to be associated with higher metastatic potential $[38,39]$.

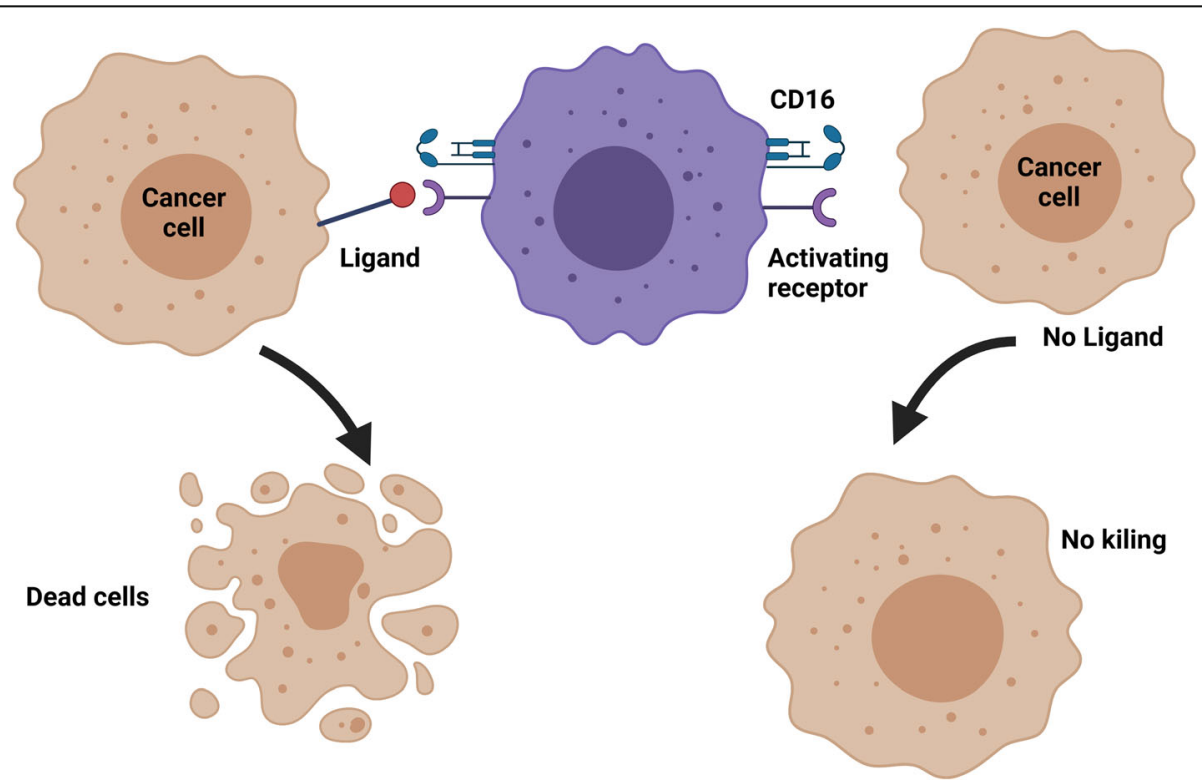

Fig. 5 Natural killer cell killing of tumor cells. Natural killer (NK) cell kills MHC class I negative tumor cells if they express surface membrane NK cell-activating ligand. Drawn using BioRender 
Increase in surface membrane sphingomyelin content leads to immune escape, and tumorigenesis initiation and progression

Remarkably, SM is apt at interacting with neighboring molecules and surrounding water molecules to generate a network of hydrogen bonds, via forming intermolecular hydrogen bonds between the glycosyl head groups, the amide and hydroxyls of the sphingosine base and of the hydroxy fatty acid. This extensive intermolecular hydrogen bonding capacity is a characteristic feature that distinguishes sphingolipids from the major lipid family in animal cells, the glycerolipids. These cannot form interlipid hydrogen bonds between their diglyceride moieties. The ester and ether groups can function only as hydrogen bond acceptors, not as donors [40-44]. Abnormal increase in SM content in surface membrane apical layer reduces membrane fluidity and permeability, and increases its rigidity and strength, leading to loss of contact inhibition and self-control mechanisms, decrease in cell to cell communication, reduced or inhibited cell surface molecules expression and signaling pathway coordination, and uncontrolled proliferation [34-39].

Following initiation of tumorigenesis, continuous increase in SM content and distribution on the cell surface membrane leads to progressive immune evasion from host effector cells and molecules, allowing tumor growth. The critical importance of SM metabolism in cancer progression is additionally due to its role in ceramide (Cer) production, because reduced SM degradation leads to decreased production of ceramide, an important signaling molecule for cancer biology including apoptosis, cell proliferation, cell migration, senescence, and inflammation [45-47]. Indeed, resistance to apoptosis is reported as one important mechanism by which tumor cells escape the action of potential immune effectors [45-51].

\section{Evidence for the role of surface membrane sphingomyelin in tumorigenesis}

Several lines of research documented the role of surface membrane SM in tumorigenesis. First, changes in sphingolipids levels were established for several tumor cells and cell lines [52-57]. More specifically, level of SM in the outer leaflet of cell plasma membrane was reported to be significantly elevated in highly metastatic human prostatic adenocarcinoma cell lines compared to the lower metastatic variant [52]. Second, SV40-transformed human lung fibroblasts synthesized SM at an abnormally fast and high rate compared to untransformed cells [58]. Third, accumulating evidence suggest that colon, prostate, and kidney cancer are also associated with alterations in sphingolipids and their metabolizing enzymes $[48,59]$. Fourth, high SM synthase expression and aberrant SM contents were associated with breast cancer progression and metastasis [60]. Fifth, increased SM content in frozen tissue samples of primary lung adenocarcinoma obtained from patients who underwent radical surgery was the most reliable indicator of recurrence, i.e., of degree of malignancy [61]. Six, low levels of surface membrane-associated neutral sphingomyelinase (nSMase)-2, responsible for SM hydrolysis, were associated with early recurrence of hepatic cell carcinoma after surgery [62]. Additionally, human hepatic cancer cell lines, HepG2 and Huh-7, were incubated with lysenin in indirect membrane immunofluorescence (IF) assays. Lysenin is SM-specific binding protein from the earthworm Eisenia foetida, which acts as a specific cytochemical probe for SM [63]. Intense surface membrane IF was displayed by HepG2 $>>>$ Huh-7 Cell lines $>$ non-cancerous cells. These results confirmed the presence of inordinate SM amount on the surface membrane of the liver cancer cells and its association with level of malignancy [64]. Indeed, sphingolipids control of the balance in cells between proliferation and apoptotic cell death has been amply documented [58].

\section{Aspects of altered sphingomyelin metabolism in cancer} Sphingomyelin is the most abundant sphingolipid in animal cell membranes, localized to the outer membrane leaflet where it greatly contributes to the formation of specialized liquid-ordered domains called lipid rafts. Sphingomyelin synthase (SMS) isoforms activity contribute to increased SM content and trafficking to the cell membrane. The activity of sphingomyelinase enzymes, notably neutral sphingomyelinase (nSMase)-2, generally localized at the plasma membrane, modulates the content of surface membrane SM via mediating its hydrolysis to ceramide and phosphocholine [40-47]. Altered sphingolipid metabolism was predicted to occur in early stages of oncogenic transformation, independently of genetic mutations, because sphingolipid metabolizing enzymes are rarely mutated [56].

Sphingomyelin metabolism in cancer cells was characterized by changes in SMS expression and activity [58]. Increased SMS expression in breast [60] and ovarian [65] cancer could be conducive to tumor metastasis. Depletion of SMS isoform 2 suppressed survival, growth, and migration of ovarian cancer cell lines, via disruption of lipid metabolism and mitochondrial function, and increase in oxidative damage [66].

Losses, mutation, and poor expression of the gene encoding nSMase were prevalent in breast and prostate cancer, and osteosarcoma cell lines $[67,68]$. Loss, reduced or aberrant expression of nSMase has been reported in colorectal, gastric, and lung cancers, lymphomas, and acute myeloid and lymphocytic leukemia [69]. Notably, gene encoding nSMase-2 was hypermethylated and silenced in hepatic cell carcinoma, 
whereby gene overexpression elicited diminished cellular proliferation by $50 \%$, and knockdown promoted tumor invasiveness and migratory capacities [62]. Hypermethylation or low expression of nSMase2-encoding gene were common events in oral squamous and renal cell carcinoma, associated with spread of tumor cells, larger tumor, higher malignancy grade, and earlier recurrence [70, 71].

Reduction in the potency of nSMase-mediated SM degradation pathway would lead to its accumulation at the apical lipid leaflet, excessive tightening of the SMbased hydrogen bond barrier and, consequently, impairment of cell-cell and cell-matrix interactions [40-44]. Marchesini et al. [72] discovered that overexpression of nSMase 2 expression causes confluence-induced growth arrest in breast cancer cells. Changes in cell nSMase2 expression, level, or activity likely led to primary tumor growth via SM accumulation on the cell membrane outer leaflet, thus interrupting cell-contact inhibition, and preventing exposure of cell surface membrane immune check points [64]. Recently, surface membrane excessive SM content in HepG2 and Huh-7 hepatic tumor cells was shown to be associated with decrease in nSMase activity. Triton-soluble surface membrane molecules of tumor and non-cancerous cells were assessed for nSMase activity using the Sphingomyelinase Amplex Red Assay of Invitrogen. The results of three independent assays revealed that nSMase activity of Hep G2 and Huh-7 tumor cells was 32 and $28 \%$ lower $(P<0.05)$ than that of normal cells, respectively. The study implicated reduced nSMase activity as responsible for high SM content in tumor cells surface membrane [64].

Ceramide is the central molecule in SM synthetic and hydrolysis pathways, and plays an important role in cancer metabolism. Balance between levels of the anti-proliferative Cer and the pro-survival action of its metabolite, sphingosine-1-phosphate, determines cell fate, and hence termed the sphingolipid rheostat of cancer cells [73]. A major mechanism of Cer generation involves hydrolysis of SM by neutral, acid, and alkaline sphingomyelinases, the former being associated with the cell plasma membrane and responsible for the control of surface membrane SM content [45-47, 4951]. The levels of SM and Cer were up- and downregulated, respectively in hepato cellular carcinoma tissues [74]. The six ceramide synthases genes were differently expressed in colorectal carcinoma, and overexpression led to impairment of the in vitro viability of cancer cell lines [75]. In support, alkaline ceramidase was found to be overexpressed in hepato cellular carcinoma tissue and cell lines, promoting cell proliferation via mediating Cer hydrolysis [76]. Breast cancer aggressiveness and proliferation were attributed to suppression of apoptosis via a Cer-associated pathway [49]. Synthesis and accumulation of Cer mediate cancer cell death via apoptosis, necroptosis, and autophagy $[45,47,77]$.

\section{Role of surface membrane sphingomyelin in metastasis and drug resistance}

Sphingomyelin is particularly enriched in tumor-derived exosomes, which contribute to cancer angiogenesis, invasion, metastasis, and drug resistance via shuttling anticancer drugs out of the tumor cells [78-81]. High SM content in cancer cell surface membrane reduces anticancer drug influx, interferes with endocytosis of nanoparticles-based drug delivery systems, and mediates drug sequestering in intracellular vesicles, major mechanisms in cancer drug resistance [82]. Content of surface membrane SM was shown to dictate the uptake level of the anti-pancreatic cancer drug, gemcitabine [83]. Cancer cells cloaked in SM-rich plasma membrane, surrounded by a tight hydrogen barrier made by interaction of SM with water molecules may traffic unscathed in blood vessels and capillaries, because host immune cells and effectors are prevented from accessing surface membrane immune checkpoint molecules, explaining the readiness of cancer cells to metastasize to distant locations [84].

\section{Impact of cancer therapy on surface membrane sphingomyelin content}

Exposure to ionizing irradiation led to rapid nSMasemediated hydrolysis of SM to Cer, and cancer cell death [85]. Resistance to traditional cancer treatments like cisplatin or irradiation was associated with nSMase inhibition, leading to SM accumulation and low Cer levels [86]. Conversely, etoposide used for the treatments of lung, testicular and ovarian cancer, lymphoma, leukemia, and neuroblastoma, and cytarabine used to treat acute myeloid leukemia, acute lymphocytic leukemia, chronic myelogenous leukemia, and non-Hodgkin's lymphoma promote nSMase activation, leading to reduced surface membrane SM content and Cer accumulation [46, 47, 69]. The phospholipid analogue miltefosine, which has been approved for the treatment of breast cancer metastasis, and is currently used for the treatment of cutaneous metastases of mammary carcinoma was shown to significantly inhibit SM biosynthesis in human hepatoma and other tumor cells [87], promote efflux of cholesterol and SM from the surface membrane [88], and modulate membrane physical properties [89]. The anti-cancer drug daunorubicin induced specific activation of nSMase-2 in the human breast cancer cell line MCF-7, leading to depletion of surface membrane SM and accumulation of intracellular Cer [90]. Arsenic trioxide anticancer activity against human multiple myeloma and gastric cancer cell lines appeared to be attributed to alterations in the sphingolipid pathway [91]. Gentamicin 


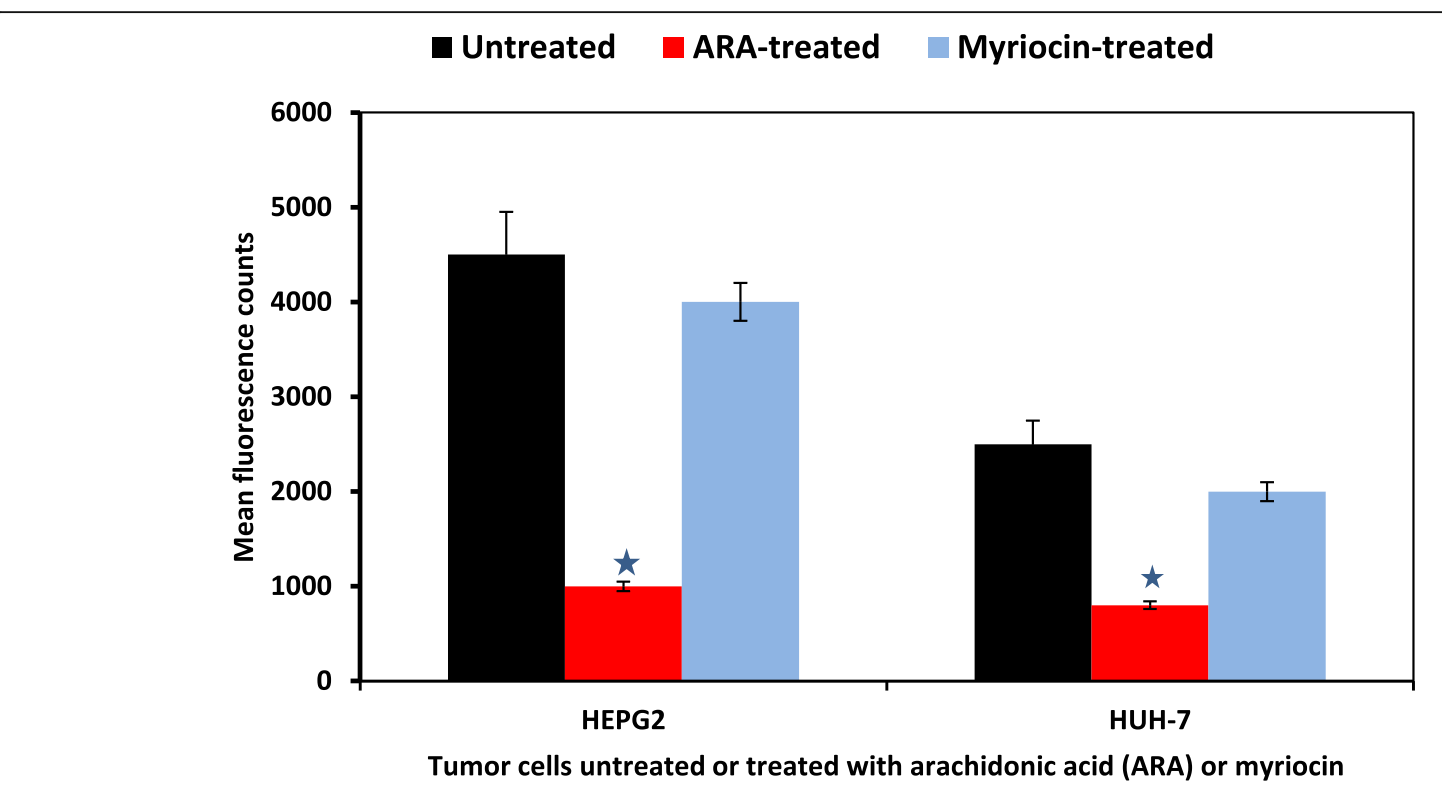

Fig. 6 Sphingomyelin metabolism and proliferative capacity of hepatic tumor cells. Mean fluorescence counts in hepatic tumor cells quantitatively assayed for proliferation by the Alamar blue microplate test, and showing significant $(P<0.005, \star)$ decrease following exposure to arachidonic acid (ARA), a known activator of nSMase, which leads to SM hydrolysis and release of intracellular apoptotic ceramide, reflected in cell viability and proliferation decrease. Myriocin interferes with SM synthesis via blocking the initial step in the de novo synthesis of ceramide, leading to reduction of SM content in the cell membrane, and reduced proliferation.

induction of delayed cell growth and cell death of Hodgkin's T-cell human lymphoblastic lymphoma acted via SM metabolism, notably nSMase stimulation in whole cells, increase in SM levels in nuclear but not outer membrane [92], and increase in cell surface elasticity [83]. Inhibition of cell proliferation and induction of apoptosis in myeloid, lymphoid, and solid cancer cell lines by Withanolide D isolated from the herb Withania somnifera, root extracts from Panax ginseg, or propolisderived caffeic acid phenethyl ester were attributed to nSMase activation-mediated production of apoptotic Cer from membrane SM [93-95].

\section{Manipulating sphingomyelin metabolism for cancer control}

Targeting SM metabolism may represent viable target for cancer cure [96-98]. This is supported by multiple reports. Blocking SM synthesis was recently found to increase immune responses to hepatic cell carcinoma, mantle cell lymphoma, and glioblastoma [99-101]. Additionally, therapeutic treatments that increased SM hydrolysis via activating the surface membrane-associated nSMase allowed tumor cell apical membrane antigens exposure to the host immune effectors and prevention of an instrumental immune escape mechanism, together with accumulation of intracellular Cer [46, 69]. Interference with SM metabolism was exploited to overcome multidrug resistance $[49,50,102]$. Specifically, inhibitors of sphingosine kinase were proposed for cancer treatment via increasing Cer levels [73].

\section{Surface membrane sphingomyelin-based prophylactic and therapeutic approaches to cancer}

The alkyl-lysophospholipid analogue edelfosine, resveratrol, miltefosine, and inhibitors of SM metabolism enzymes were used to alter tumor cell membrane fluidity and permeability and showed remarkable efficacy in preventing tumor progression [54, 85, 103, 104]. Devising novel anticancer strategies based on the modulation of lipid metabolism and the composition of the cell membrane was recently advised for the treatment of cancer and overcoming drug resistance, pioneering a novel field named membrane-lipid therapy [104-106]. Combination of chemotherapeutic drugs and Cer is presently increasingly used for tumor treatment [47, 51, 107-109]. Increasing the activity of nSMase 2 led to overcoming immune escape in melanoma cells [110]. Arachidonic acid (ARA), a potent nSMase activator, was shown to attenuate leukemia-derived HL-60, gastric, prostate and breast cancer cells growth via nSMase activation pathways [111-113]. Arachidonic acid was advocated as having the potential to increase the efficacy of currently used glioma treatments via its activation of nSMase [114]. Additionally, activation of HepG2 and Huh-7 tumor cells with ARA led to considerable decrease in surface membrane SM content as assessed using the lysenin test, increase in nSMase activity as judged by the 
Sphingomyelinase Amplex Red Assay, likely mediating highly significant $(P<0.0001)$ reduction in HepG2 and Huh-7 tumor cells proliferation level in the Alamar blue test (Fig. 6) [64]. These results are in entire accord with the reports documenting ARA selective tumoricidal action $[115,116]$.

\section{Study strength and limitations}

In this review the role of the cell surface membrane SM in tumor initiation, progression, and metastasis was emphasized for the first time. Proposals in this review are directly and indirectly supported by a large number of published studies and findings. The review is, however, limited by the lack of experiments and trials dedicated to the assessment of the validity and efficacy of antitumor therapies based on reducing the level and distribution of sphingomyelin in experimental animals and humans.

\section{Conclusions and further perspectives}

Cancer that becomes clinically detectable has evaded immunological surveillance, possibly due to failure of properly exposing cell surface membrane molecules, which are instrumental in interaction with the host immune effectors. Immunotherapy strategies may, therefore, not be of significant use. Future cancer management strategies should be directed at elucidating the fundamental flaw leading to low or absent surface membrane expression of molecules critical for tumor eradication. The review proposes that cell surface membrane SM accumulation, propensity to form intermolecular hydrogen bond barrier with adjacent molecules and surrounding water, and impairment of a major generation mechanism of the pro-apoptic Cer are instrumental in tumor initiation, progression, and metastasis. Innumerable published findings, reports, and studies supporting the hypothesis were presented. The recent progress in membrane-lipid therapy was delineated. Treatment with ARA, the membrane-associated nSMase- 2 powerful activator, was proposed for prevention of tumor cells immune evasion and cancer management via hydrolysis of surface membrane SM, allowing proper cell-cell-contact inhibition, exposure of immune check molecules, and release of vigorous apoptotic signals. Experiments will be designed to assess the impact of ARA and other molecules capable of modulating the cell surface SM content in preventing tumor initiation, reversing tumor growth, and preventing cancer cells locomotion, migration, and metastasis in experimental hosts. Possible safe and highly efficacious prophylactic and therapeutic agents and molecules will be proposed for pre-clinical trials in experimental hosts and humans.

\section{Abbreviations}

SM: Sphingomyelin; MHC: Major histocompatibility complex; TAA: Tumorassociated antigen.; TSA: Tumor-specific antigen; NK: Natural killer; TNF: Tumor necrosis factor; IFN-Y: Interefon gamma; Cer: Ceramide; SMase: Sphingomyelinase; nSMase: neutral sphingomyelinase;

SMS: Sphingomyelin synthase; ARA: Arachidonic acid

Acknowledgements

The excellent suggestions and comments of the Reviewers are herein acknowledged.

\section{Authors' contributions}

All authors have contributed, wrote, revised and reviewed the manuscript and approved the final version of the revised manuscript. All authors read and approved the final manuscript.

\section{Funding}

None.

Availability of data and materials

Not Applicable. Data sharing is not applicable to this article as no datasets were generated or analyzed during the current study.

\section{Declarations}

Ethics approval and consent to participate

Not applicable.

\section{Consent for publication}

Not applicable.

\section{Competing interests}

The authors declare they have no financial or otherwise competing interests.

Received: 25 August 2021 Accepted: 15 October 2021

Published online: 31 October 2021

\section{References}

1. Burke KP, Grebinoski S, Sharpe AH, Vignali DAA. Understanding adverse events of immunotherapy: a mechanistic perspective. J Exp Med. 2021; 218(1):e20192179. https://doi.org/10.1084/jem.20192179.

2. Klein J, Sato A. The HLA system. First of two parts. N Engl J Med. 2000; 343(10):702-9. https://doi.org/10.1056/NEJM200009073431006.

3. Ribatti D. A revisited concept: Contact inhibition of growth. From cell biology to malignancy. Exp Cell Res. 2017;359(1):17-9. https://doi.org/10.101 6/j.yexcr.2017.06.012

4. Liu CC, Yang H, Zhang R, Zhao JJ, Hao DJ. Tumour-associated antigens and their anti-cancer applications. Eur J Cancer Care (Engl). 2017:26(5):e12446. https://doi.org/10.1111/ecc.12446.

5. Thongprasert S, Yang PC, Lee JS, Soo R, Gruselle O, Myo A, et al. The prevalence of expression of MAGE-A3 and PRAME tumor antigens in East and South East Asian non-small cell lung cancer patients. Lung Cancer. 2016;101:137-44. https://doi.org/10.1016/j.lungcan.2016.09.006.

6. Gnjatic $S$, Nishikawa $H$, Jungbluth $A A$, Güre $A O$, Ritter $G$, Jäger $E$, et al. NYESO-1: Review of an immunogenic tumor antigen. Adv Cancer Res. 2006;95: 1-30. Review. https://doi.org/10.1016/S0065-230X(06)95001-5.

7. Liang J, Ding T, Guo ZW, Yu XJ, Hu YZ, Zheng L, et al. Expression pattern of tumour-associated antigens in hepatocellular carcinoma: association with immune infiltration and disease progression. Br J Cancer. 2013;109(4):10319. https://doi.org/10.1038/bjc.2013.390.

8. Xue L, Hu Y, Wang J, Liu X, Wang X. T cells targeting multiple tumorassociated antigens as a postremission treatment to prevent or delay relapse in acute myeloid leukemia. Cancer Manag Res. 2019;11:6467-76. https://doi.org/10.2147/CMAR.S205296.

9. Smith HA, MCNeel DG. The SSX family of cancer-testis antigens as target proteins for tumor therapy. Clin Dev Immunol. 2010;2010:150591-18. https://doi.org/10.1155/2010/150591.

10. Johansen S, Gjerstorff MF. Interaction between Polycomb and SSX proteins in pericentromeric heterochromatin function and its implication in cancer. Cells. 2020;9(1):226. https://doi.org/10.3390/cells9010226. 
11. Muramatsu T. Midkine, a heparin-binding cytokine with multiple roles in development, repair and diseases. Proc Jpn Acad Ser B Phys Biol Sci. 2010 86(4):410-25. Review. https://doi.org/10.2183/pjab.86.410.

12. Garg H, Suri P, Gupta JC, Talwar GP, Dubey S. Survivin: a unique target for tumor therapy. Cancer Cell Int. 2016;16:49. https://doi.org/10.1186/s12935-01 6-0326-1.

13. Chen $L$, Pan $X$, Zeng $T$, Zhang $Y H$, Zhang $Y$, Huang $T$, et al. Immunosignature screening for multiple cancer subtypes based on expression rule. Front Bioeng Biotechnol. 2019;7:370. https://doi.org/10.33 89/fbioe.2019.00370

14. Fusciello M, Fontana F, Tähtinen S, Capasso C, Feola S, Martins B, et al. Artificially cloaked viral nanovaccine for cancer immunotherapy. Nat Commun. 2019;10(1):5747. https://doi.org/10.1038/s41467-019-13744-8.

15. Hollingsworth RE, Jansen K. Turning the corner on therapeutic cancer vaccines. NPJ Vaccines. 2019;4(1):7. https://doi.org/10.1038/s41467-019-13 744-8.

16. Löffler MW, Kowalewski DJ, Backert L, Bernhardt J, Adam P, Schuster H, et al. Mapping the HLA ligandome of colorectal cancer reveals an imprint of malignant cell transformation. Cancer Res. 2018;78(16):4627-41. https://doi. org/10.1158/0008-5472.CAN-17-1745.

17. Hu ZI, McArthur HL, Ho AY. The abscopal effect of radiation therapy: What is it and how can we use it in breast cancer. Curr Breast Cancer Rep. 2017;9(1): 45-51. https://doi.org/10.1007/s12609-017-0234-y.

18. Widel M. Radionuclides in radiation-induced bystander effect; may it share in radionuclide therapy. Neoplasma. 2017;64(5):641-54. https://doi.org/1 0.4149/neo_2017_501 Review.

19. Löffler MW, Nussbaum B, Jäger G, Jurmeister PS, Budczies J, Pereira PL, et al. A Non-interventional clinical trial assessing immune responses after radiofrequency ablation of liver metastases from colorectal cancer. Front Immunol. 2019:10:2526. https://doi.org/10.3389/fimmu.2019.02526.

20. Bubeník J. Tumour MHC class I downregulation and immunotherapy (Review). Oncol Rep. 2003;10(6):2005-8. https://doi.org/10.3892/or.10.6.2005.

21. Morrison BJ, Steel JC, Morris JC. Reduction of MHC-I expression limits Tlymphocyte-mediated killing of cancer-initiating cells. BMC Cancer. 2018; 18(1):469. https://doi.org/10.1186/s12885-018-4389-3.

22. Garrido F. MHC/HLA Class I loss in cancer cells. Adv Exp Med Biol. 2019; 1151:15-78. https://doi.org/10.1007/978-3-030-17864-2_2.

23. Cornel AM, Mimpen IL, Nierkens S. MHC class I downregulation in cancer: underlying mechanisms and potential targets for cancer immunotherapy. Cancers (Basel). 2020:12(7):1760. https://doi.org/10.3390/cancers12071760.

24. Waring $P$, Müllbacher A. Cell death induced by the Fas/Fas ligand pathway and its role in pathology. Immunol Cell Biol. 1999;77(4):312-7. https://doi. org/10.1046/j.1440-1711.1999.00837.x.

25. Zhou L, Wang W, Dicker DT, Humphreys RC, El-Deiry WS. Prediction of proapoptotic anticancer therapeutic response in vivo based on cell death visualization and TRAIL death ligand-receptor interaction. Cancer Biol Ther 2011:12(4):335-48. https://doi.org/10.4161/cbt.12.4.1717.

26. Konjević G, Vuletić A, Mirjačić MK. Natural killer cell receptors: alterations and therapeutic targeting in malignancies. Immunol Res. 2016;64(1):25-35. https://doi.org/10.1007/s12026-015-8695-4

27. Sabry M, Lowdell MW. Tumor-primed NK cells: waiting for the green light. Front Immunol. 2013;4:408. https://doi.org/10.3389/fimmu.2013. 00408.

28. Liu H, Wang S, Xin J, Wang J, Yao C, Zhang Z. Role of NKG2D and its ligands in cancer immunotherapy. Am J Cancer Res. 2019;9(10):2064-78.

29. Malmberg KJ, Carlsten M, Björklund A, Sohlberg E, Bryceson YT, Ljunggren HG. Natural killer cell-mediated immunosurveillance of human cancer. Semin Immunol. 2017;31:20-9. https://doi.org/10.1016/j.smim.2017.08.002.

30. Kolben $T$, Jeschke $U$, Reimer $T$, Karsten N, Schmoeckel E, Semmlinger A, et al. Induction of apoptosis in breast cancer cells in vitro by Fas ligand reverse signaling. J Cancer Res Clin Oncol. 2018;144(2):249-56. https://doi. org/10.1007/s00432-017-2551-y.

31. Di Vito C, Mikulak J, Zaghi E, Pesce S, Marcenaro E, Mavilio D. NK cells to cure cancer. Semin Immunol. 2019;41:101272. https://doi.org/10.1016/j. smim.2019.03.004.

32. Duan $\mathrm{S}$, Guo W, Xu Z, He Y, Liang $C$, Mo Y, et al. Natural killer group $2 \mathrm{D}$ receptor and its ligands in cancer immune escape. Mol Cancer. 2019;18(1): 29. https://doi.org/10.1186/s12943-019-0956-8.

33. Lazarova M, Steinle A. The NKG2D axis: an emerging target in cancer immunotherapy. Expert Opin Ther Targets. 2019;23(4):281-94. https://doi. org/10.1080/14728222.2019.1580693.
34. Purdom L, Ambrose EJ, Klein G. A correlation between electrical surface charge and some biological characteristics during the stepwise progression of a mouse sarcoma. Nature. 1958;181(4623):1586-7. https://doi.org/10.103 8/1811586a0.

35. Abercrombie M, Ambrose EJ. The surface properties of cancer cells: a review. Cancer Res. 1962:22:525-48.

36. Nicolson GL. Cell surface properties of metastatic tumor cells. In: Liotta LA, Hart IR, editors. Tumor Invasion and Metastasis. Developments in Oncology, vol. 7. Dordrecht: Springer; 1982. p. 57-80.

37. Joshi SS, Tilden PA, Jackson JD, Sharp JG, Brunson KW. Cell surface properties associated with malignancy of metastatic large cell lymphoma cells. Cancer Res. 1987:47(13):3551-7.

38. Tressler RJ, Nicolson GL. Butanol-extractable and detergent-solubilized cell surface components from murine large cell lymphoma cells associated with adhesion to organ microvessel endothelial cells. J Cell Biochem. 1992:48(2): 162-71. https://doi.org/10.1002/jcb.240480208

39. Dobrzyńska I, Szachowicz-Petelska B, Darewicz B, Figaszewski ZA. Characterization of human bladder cell membrane during cancer transformation. J Membr Biol. 2015;248(2):301-7. https://doi.org/10.1007/ s00232-015-9770-4.

40. Barenholz Y, Thompson TE. Sphingomyelin: biophysical aspects. Chem Phys Lipids. 1999;102(1-2):29-34. https://doi.org/10.1016/s0009-3084(99)00072-9.

41. Mombelli E, Morris R, Taylor W, Fraternali F. Hydrogen-bonding propensities of sphingomyelin in solution and in a bilayer assembly: a molecular dynamics study. Biophys J. 2003;84(3):1507-17. https://doi.org/10.1016/ S0006-3495(03)74963-7.

42. Slotte JP. Biological functions of sphingomyelins. Prog Lipid Res. 2013;52(4): 424-37. https://doi.org/10.1016/j.plipres.2013.05.001.

43. Migliardo F, Tallima H, El Ridi R. Is there a sphingomyelin-based hydrogen bond barrier at the mammalian host-schistosome parasite interface. Cell Biochem Biophys. 2014;68(2):359-67. https://doi.org/10.1007/s12013-013-9716-3.

44. Slotte JP. The importance of hydrogen bonding in sphingomyelin's membrane interactions with co-lipids. Biochim Biophys Acta. 2016;1858(2): 304-10. https://doi.org/10.1016/j.bbamem.2015.12.008.46.

45. Mullen TD, Obeid LM. Ceramide and apoptosis: exploring the enigmatic connections between sphingolipid metabolism and programmed cell death. Anti Cancer Agents Med Chem. 2012;12(4):340-63. Review. https:// doi.org/10.2174/187152012800228661.

46. D'Angelo G, Moorthi S, Luberto C. Role and function of sphingomyelin biosynthesis in the development of cancer. Adv Cancer Res. 2018;140:61-96. Review. https://doi.org/10.1016/bs.acr.2018.04.009.

47. Ogretmen B. Sphingolipid metabolism in cancer signalling and therapy. Nat Rev Cancer. 2018;18(1):33-50. https://doi.org/10.1038/nrc.2017.96.

48. Radin NS. Cancer progression in the kidney and prostate: vital roles of sphingolipids in chemotherapy. Urology. 2002;60(4):562-8. https://doi.org/1 0.1016/s0090-4295(02)01755-7.

49. Morad SA, Cabot MC. Ceramide-orchestrated signalling in cancer cells. Nat Rev Cancer. 2013;13(1):51-65. https://doi.org/10.1038/nrc3398

50. Galadari S, Rahman A, Pallichankandy S, Thayyullathil F. Tumor suppressive functions of ceramide: evidence and mechanisms. Apoptosis. 2015;20(5): 689-711. https://doi.org/10.1007/s10495-015-1109-1.

51. Nganga R, Oleinik N, Ogretmen B. Mechanisms of ceramide-dependent cancer cell death. Adv Cancer Res. 2018;140:1-25. https://doi.org/10.1016/ bs.acr.2018.04.007 Review.

52. Dahiya R, Boyle B, Goldberg BC, Yoon WH, Konety B, Chen K, et al. Metastasis-associated alterations in phospholipids and fatty acids of human prostatic adenocarcinoma cell lines. Biochem Cell Biol. 1992;70(7):548-54. https://doi.org/10.1139/092-085.

53. Veldman RJ, Klappe K, Hinrichs J, Hummel I, van der Schaaf G, Sietsma H, et al. Altered sphingolipid metabolism in multidrug-resistant ovarian cancer cells is due to uncoupling of glycolipid biosynthesis in the Golgi apparatus. FASEB J. 2002;16(9):1111-3. https://doi.org/10.1096/fj.01-0863fje.

54. Delgado A, Fabrias G, Bedia C, Casas J, Abad JL. Sphingolipid modulation: a strategy for cancer therapy. Anti Cancer Agents Med Chem. 2012;12(4):285302. https://doi.org/10.2174/187152012800228643.

55. García-Barros M, Coant N, Truman JP, Snider AJ, Hannun YA. Sphingolipids in colon cancer. Biochim Biophys Acta. 2014;1841(5):773-82. https://doi. org/10.1016/j.bbalip.2013.09.007.

56. Lee WK, Kolesnick RN. Sphingolipid abnormalities in cancer multidrug resistance: chicken or egg. Cell Signal. 2017;38:134-45. https://doi.org/10.101 6/j.cellsig.2017.06.017. 
57. Monzen S, Tatara Y, Mariya Y, Chiba M, Wojcik A, Lundholm L. HER2-positive breast cancer that resists therapeutic drugs and ionizing radiation releases sphingomyelin-based molecules to circulating blood serum. Mol Clin Oncol. 2020;13(6):70. https://doi.org/10.3892/mco.2020.2140.

58. Luberto C, Hannun YA. Sphingomyelin synthase, a potential regulator of intracellular levels of ceramide and diacylglycerol during SV40 transformation. Does sphingomyelin synthase account for the putative phosphatidylcholine-specific phospholipase C. J Biol Chem. 1998;273(23): 14550-9. https://doi.org/10.1074/jbc.273.23.14550.

59. Vykoukal J, Fahrmann JF, Gregg JR, Tang Z, Basourakos S, Irajizad E, et al. Caveolin-1-mediated sphingolipid oncometabolism underlies a metabolic vulnerability of prostate cancer. Nat Commun. 2020;11(1):4279. https://doi. org/10.1038/s41467-020-17645-z.

60. Zheng $K$, Chen Z, Feng H, Chen Y, Zhang C, Yu J, et al. Sphingomyelin synthase 2 promotes an aggressive breast cancer phenotype by disrupting the homoeostasis of ceramide and sphingomyelin. Cell Death Dis. 2019; 10(3):157. https://doi.org/10.1038/s41419-019-1303-0.

61. Takanashi Y, Funai K, Sato S, Kawase A, Tao H, Takahashi Y, et al. Sphingomyelin (d35:1) as a novel predictor for lung adenocarcinoma recurrence after a radical surgery: a case-control study. BMC Cancer. 2020; 20(1):800. https://doi.org/10.1186/s12885-020-07306-1.

62. Revill K, Wang T, Lachenmayer A, Kojima K, Harrington A, Li J, et al. Genome-wide methylation analysis and epigenetic unmasking identify tumor suppressor genes in hepatocellular carcinoma. Gastroenterology. 2013;145(6):1424-35.e1-25. https://doi.org/10.1053/j.gastro.2013.08.055

63. Yamaji A, Sekizawa Y, Emoto K, Sakuraba H, Inoue K, Kobayashi H, et al. Lysenin, a novel sphingomyelin-specific binding protein. J Biol Chem. 1998; 273(9):5300-6. https://doi.org/10.1074/jbc.273.9.5300.

64. Tallima H. Surface Membrane Sphingomyelin and Carcinogenesis. In: The 16th Annual Conference of the National Biochemistry and Molecular Biology Committee, Egyptian Academy of Scientific Research and Technology. New Cairo: The American University in Cairo; 2019.

65. Jing F, Jing C, Dai X, Zhou G, Di S, Bi X, et al. Sphingomyelin synthase 2 but not sphingomyelin synthase 1 is upregulated in ovarian cancer and involved in migration, growth and survival via different mechanisms. Am J Transl Res. 2021;13(5):4412-21.

66. Don AS, Lim XY, Couttas TA. Re-configuration of sphingolipid metabolism by oncogenic transformation. Biomolecules. 2014;4(1):315-53. https://doi. org/10.3390/biom4010315.

67. Driouch $\mathrm{K}$, Dorion-Bonnet $F$, Briffod M, Champéme MH, Longy M, Lidereau R. Loss of heterozygosity on chromosome arm $16 \mathrm{q}$ in breast cancer metastases. Genes Chromosom Cancer. 1997;19(3):185-91. https://doi.org/1 0.1002/(sici)1098-2264(199707)19:3<185::aid-gcc8>3.0.co;2-u

68. Kim WJ, Okimoto RA, Purton LE, Goodwin M, Haserlat SM, Dayyani F, et al. Mutations in the neutral sphingomyelinase gene SMPD3 implicate the ceramide pathway in human leukemias. Blood. 2008;111(9):4716-22. https:// doi.org/10.1182/blood-2007-10-113068.

69. Clarke CJ. Neutral sphingomyelinases in cancer: friend or foe. Adv Cancer Res. 2018;140:97-119. https://doi.org/10.1016/bs.acr.2018.04.010.

70. Wang J, Li J, Gu J, Yu J, Guo S, Zhu Y, et al. Abnormal methylation status of FBXW10 and SMPD3, and associations with clinical characteristics in clear cell renal cell carcinoma. Oncol Lett. 2015;10(5):3073-80. https://doi.org/10.3 892/ol.2015.3707.

71. Jabalee J, Towle R, Lawson J, Dickman C, Garnis C. Sphingomyelin phosphodiesterase 3 methylation and silencing in oral squamous cell carcinoma results in increased migration and invasion and altered stress response. Oncotarget. 2020;11(5):523-34. https://doi.org/10.18632/oncota rget. 27458 .

72. Marchesini N, Osta W, Bielawski J, Luberto C, Obeid LM, Hannun YA. Role for mammalian neutral sphingomyelinase 2 in confluence-induced growth arrest of MCF7 cells. J Biol Chem. 2004;279(24):25101-11. https://doi.org/10.1 074/jbc.M313662200

73. Newton J, Lima S, Maceyka M, Spiegel S. Revisiting the sphingolipid rheostat: Evolving concepts in cancer therapy. Exp Cell Res. 2015;333(2):195200. https://doi.org/10.1016/j.yexcr.2015.02.025

74. Li Z, Guan M, Lin Y, Cui X, Zhang Y, Zhao Z, et al. Aberrant lipid metabolism in hepatocellular carcinoma revealed by liver lipidomics. Int J Mol Sci. 2017; 18(12):2550. https://doi.org/10.3390/ijms18122550.

75. Jang SW, Park WJ, Min H, Kwon TK, Baek SK, Hwang I, et al. Altered mRNA expression levels of the major components of sphingolipid metabolism, ceramide synthases and their clinical implication in colorectal cancer. Oncol Rep. 2018;40(6):3489-500. https://doi.org/10.3892/or.2018.6712.

76. Liu B, Xiao J, Dong M, Qiu Z, Jin J. Human alkaline ceramidase 2 promotes the growth, invasion, and migration of hepatocellular carcinoma cells via sphingomyelin phosphodiesterase acid-like 3B. Cancer Sci. 2020;111(7): 2259-74. https://doi.org/10.1111/cas.14453.

77. Sheridan M, Ogretmen B. The Role of ceramide metabolism and signaling in the regulation of mitophagy and cancer therapy. Cancers (Basel). 2021; 13(10):2475. https://doi.org/10.3390/cancers13102475.

78. Safaei R, Larson BJ, Cheng TC, Gibson MA, Otani S, Naerdemann W, et al. Abnormal lysosomal trafficking and enhanced exosomal export of cisplatin in drug-resistant human ovarian carcinoma cells. Mol Cancer Ther. 2005; 4(10):1595-604. https://doi.org/10.1158/1535-7163.MCT-05-0102.

79. Mashouri L, Yousefi H, Aref AR, Ahadi AM, Molaei F, Alahari SK. Exosomes: composition, biogenesis, and mechanisms in cancer metastasis and drug resistance. Mol Cancer. 2019;18(1):75. https://doi.org/10.1186/s12943-0190991-5.

80. Jafari A, Babajani A, Abdollahpour-Alitappeh M, Ahmadi N, Rezaei-Tavirani M. Exosomes and cancer: from molecular mechanisms to clinical applications. Med Oncol. 2021;38(4):45. https://doi.org/10.1007/s12032-02101491-0.

81. Santos NL, Bustos SO, Bhatt D, Chammas R, Andrade LNS. Tumor-derived extracellular vesicles: modulation of cellular functional dynamics in tumor microenvironment and its clinical implications. Front Cell Dev Biol. 2021;9: 737449. https://doi.org/10.3389/fcell.2021.737449.

82. Peetla C, Vijayaraghavalu S, Labhasetwar V. Biophysics of cell membrane lipids in cancer drug resistance: Implications for drug transport and drug delivery with nanoparticles. Adv Drug Deliv Rev. 2013;65(13-14):1686-98. https://doi.org/10.1016/j.addr.2013.09.004.

83. Materon EM, Nascimento GF, Shimizu FM, Câmara AS, Sandrino B, Faria $\mathrm{RC}$, et al. Role of sphingomyelin on the interaction of the anticancer drug gemcitabine hydrochloride with cell membrane models. Colloids Surf B Biointerfaces. 2020;196:111357. https://doi.org/10.1016/j.colsurfb.2 020.111357.

84. Nicolson GL. Cell membrane fluid-mosaic structure and cancer metastasis. Cancer Res. 2015;75(7):1169-76. https://doi.org/10.1158/0008-5472.CA $\mathrm{N}-14-3216$.

85. Haimovitz-Friedman A, Kan CC, Ehleiter D, Persaud RS, McLoughlin M, Fuks $Z$, et al. lonizing radiation acts on cellular membranes to generate ceramide and initiate apoptosis. J Exp Med. 1994;180(2):525-35. https://doi.org/10.1 084/jem.180.2.525

86. Zalba S, Ten Hagen TL. Cell membrane modulation as adjuvant in cancer therapy. Cancer Treat Rev. 2017;52:48-57. https://doi.org/10.1016/j.ctrv.201 6.10 .008 .

87. Marco C, Jiménez-López JM, Ríos-Marco P, Segovia JL, Carrasco MP. Hexadecylphosphocholine alters nonvesicular cholesterol traffic from the plasma membrane to the endoplasmic reticulum and inhibits the synthesis of sphingomyelin in HepG2 cells. Int J Biochem Cell Biol. 2009;41(6):1296303. https://doi.org/10.1016/j.biocel.2008.11.004.

88. Ríos-Marco P, Segovia JL, Jiménez-López JM, Marco C, Carrasco MP. Lipid efflux mediated by alkylphospholipids in HepG2 cells. Cell Biochem Biophys. 2013;66(3):737-46. https://doi.org/10.1007/s12013-013-9518-7.

89. Zulueta Díaz YLM, Ambroggio EE, Fanani ML. Miltefosine inhibits the membrane remodeling caused by phospholipase action by changing membrane physical properties. Biochim Biophys Acta Biomembr. 2020; 1862(10):183407. https://doi.org/10.1016/j.bbamem.2020.183407.

90. Ito H, Murakami M, Furuhata A, Gao S, Yoshida K, Sobue S, et al. Transcriptional regulation of neutral sphingomyelinase 2 gene expression of a human breast cancer cell line, MCF-7, induced by the anti-cancer drug, daunorubicin. Biochim Biophys Acta. 2009;1789(11-12):681-90. https://doi. org/10.1016/j.bbagrm.2009.08.006.

91. Zou J, Ma X, Zhang G, Shen L, Zhou L, Yu Y, et al. Evaluation of the change in sphingolipids in the human multiple myeloma cell line U266 and gastric cancer cell line MGC-803 treated with arsenic trioxide. J Chromatogr B Anal Technol Biomed Life Sci. 2015;1004:98-107. https://doi.org/10.1016/j. jchromb.2015.09.015.

92. Codini M, Cataldi S, Ambesi-Impiombato FS, Lazzarini A, Floridi A, Lazzarini $\mathrm{R}$, et al. Gentamicin arrests cancer cell growth: the intriguing involvement of nuclear sphingomyelin metabolism. Int J Mol Sci. 2015;16(2):2307-19. https://doi.org/10.3390/ijms16022307. 
93. Mondal S, Mandal C, Sangwan R, Chandra S, Mandal C. Withanolide D induces apoptosis in leukemia by targeting the activation of neutral sphingomyelinase-ceramide cascade mediated by synergistic activation of c-Jun N-terminal kinase and p38 mitogen-activated protein kinase. Mol Cancer. 2010;9(1):239. https://doi.org/10.1186/1476-4598-9-239.

94. Park B, Lee YM, Kim JS, Her Y, Kang JH, Oh SH, et al. Neutral sphingomyelinase 2 modulates cytotoxic effects of protopanaxadiol on different human cancer cells. BMC Complement Altern Med. 2013;13(1):194. https://doi.org/10.1186/1472-6882-13-194.

95. Tseng $\mathrm{TH}$, Shen $\mathrm{CH}$, Huang WS, Chen CN, Liang WH, Lin TH, et al. Activation of neutral-sphingomyelinase, MAPKs, and p75 NTR-mediating caffeic acid phenethyl ester-induced apoptosis in C6 glioma cells. J Biomed Sci. 2014; 21(1):61. https://doi.org/10.1186/1423-0127-21-61.

96. Milhas D, Clarke CJ, Hannun YA. Sphingomyelin metabolism at the plasma membrane: implications for bioactive sphingolipids. FEBS Lett. 2010;584(9): 1887-94. https://doi.org/10.1016/j.febslet.2009.10.058.

97. Taniguchi M, Okazaki T. The role of sphingomyelin and sphingomyelin synthases in cell death, proliferation and migration-from cell and animal models to human disorders. Biochim Biophys Acta. 2014;1841(5):692-703. https://doi.org/10.1016/j.bbalip.2013.12.003.

98. Shaw J, Costa-Pinheiro P, Patterson L, Drews K, Spiegel S, Kester M. Novel sphingolipid-based cancer therapeutics in the personalized medicine era. Adv Cancer Res. 2018;140:327-66. https://doi.org/10.1016/bs.acr.2018.04.016.

99. Lee MS, Sun W, Webb TJ. Sphingosine kinase blockade leads to increased natural killer T cell responses to mantle cell lymphoma. Cells. 2020;9(4):1030. https://doi.org/10.3390/cells9041030.

100. Grbčić $P$, Car EPM, Sedić M. Targeting ceramide metabolism in hepatocellular carcinoma: new points for therapeutic intervention. Curr Med Chem. 2020;27(39):6611-27. https://doi.org/10.2174/09298673266661 90911115722.

101. Tea MN, Poonnoose SI, Pitson SM. Targeting the sphingolipid system as a therapeutic direction for glioblastoma. Cancers (Basel). 2020;12(1):111. Review. https://doi.org/10.3390/cancers12010111.

102. Kok JW, Sietsma H. Sphingolipid metabolism enzymes as targets for anticancer therapy. Curr Drug Targets. 2004;5(4):375-82. https://doi.org/1 $0.2174 / 1389450043345452$

103. Baritaki S, Apostolakis S, Kanellou P, Dimanche-Boitrel MT, Spandidos DA, Bonavida B. Reversal of tumor resistance to apoptotic stimuli by alteration of membrane fluidity: therapeutic implications. Adv Cancer Res. 2007;98: 149-90. https://doi.org/10.1016/S0065-230X(06)98005-1.

104. Escribá PV. Membrane-lipid therapy: A historical perspective of membrane targeted therapies - From lipid bilayer structure to the pathophysiological regulation of cells. Biochim Biophys Acta Biomembr. 2017;1859(9 Pt B): 1493-506. https://doi.org/10.1016/j.bbamem.2017.05.017.

105. Preta G. New insights into targeting membrane lipids for cancer therapy/ front cell. Dev Biol. 2020;8:571237. https://doi.org/10.3389/fcell.2020.571237.

106. Pakiet A, Sikora K, Kobiela J, Rostkowska O, Mika A, Sledzinski T. Alterations in complex lipids in tumor tissue of patients with colorectal cancer. Lipids Health Dis. 2021;20(1):85. https://doi.org/10.1186/s12944-021-01512-x.

107. Li F, Zhang N. Ceramide: Therapeutic potential in combination therapy for cancer treatment. Curr Drug Metab. 2015;17(1):37-51. https://doi.org/10.21 74/1389200216666151103120338.

108. Ma YY, Mou XZ, Ding YH, Zou H, Huang DS. Delivery systems of ceramide in targeted cancer therapy: ceramide alone or in combination with other anti-tumor agents. Expert Opin Drug Deliv. 2016;13(10):1397-406. https:// doi.org/10.1080/17425247.2016.1188803.

109. Liu L, Ye Q, Liu L, Bihl JC, Chen Y, Liu J, et al. C6-ceramide treatment inhibits the proangiogenic activity of multiple myeloma exosomes via the miR-29b/ Akt pathway. J Transl Med. 2020;18(1):298. https://doi.org/10.1186/s12967-02 0-02468-9.

110. Montfort A, Bertrand F, Rochotte J, Gilhodes J, Filleron T, Milhès J, et al. Neutral sphingomyelinase 2 heightens anti-melanoma immune responses and anti-PD-1 therapy efficacy. Cancer Immunol Res. 2021;9(5):568-82. https://doi.org/10.1158/2326-6066.CIR-20-0342

111. Das UN. Gamma-linolenic acid, arachidonic acid, and eicosapentaenoic acid as potential anticancer drugs. Nutrition. 1990;6(6):429-34

112. Dai J, Shen J, Pan W, Shen S, Das UN. Effects of polyunsaturated fatty acids on the growth of gastric cancer cells in vitro. Lipids Health Dis. 2013;12(1): 71. https://doi.org/10.1186/1476-511X-12-71.

113. Meng $H$, Shen $Y$, Shen J, Zhou F, Shen S, Das UN. Effect of $n-3$ and $n-6$ unsaturated fatty acids on prostate cancer (PC-3) and prostate epithelial
(RWPE-1) cells in vitro. Lipids Health Dis. 2013;12(1):160. https://doi.org/10.11 86/1476-511X-12-160

114. Omahen DA. Augmentation of chemotherapy-triggered glioma cell apoptosis by blockade of arachidonic acid metabolism--the potential role of ceramide accumulation. Med Hypotheses. 2011;77(5):726-33. https://doi. org/10.1016/j.mehy.2011.07.025.

115. Ortea I, González-Fernández MJ, Ramos-Bueno RP, Guil-Guerrero JL. Proteomics study reveals that docosahexaenoic and arachidonic acids exert different in vitro anticancer activities in colorectal cancer cells. J Agric Food Chem. 2018;66(24):6003-12. https://doi.org/10.1021/acs.jafc.8b00915.

116. González-Fernández MJ, Fabrikov D, Ramos-Bueno RP, Guil-Guerrero JL, Ortea I. SWATH differential abundance proteomics and cellular assays show in vitro anticancer activity of arachidonic acid- and docosahexaenoic acidbased monoacylglycerols in HT-29 colorectal cancer cells. Nutrients. 2019; 11(12):2984. https://doi.org/10.3390/nu11122984.

\section{Publisher's Note}

Springer Nature remains neutral with regard to jurisdictional claims in published maps and institutional affiliations.

Ready to submit your research? Choose BMC and benefit from:

- fast, convenient online submission

- thorough peer review by experienced researchers in your field

- rapid publication on acceptance

- support for research data, including large and complex data types

- gold Open Access which fosters wider collaboration and increased citations

- maximum visibility for your research: over $100 \mathrm{M}$ website views per year

At BMC, research is always in progress.

Learn more biomedcentral.com/submissions 